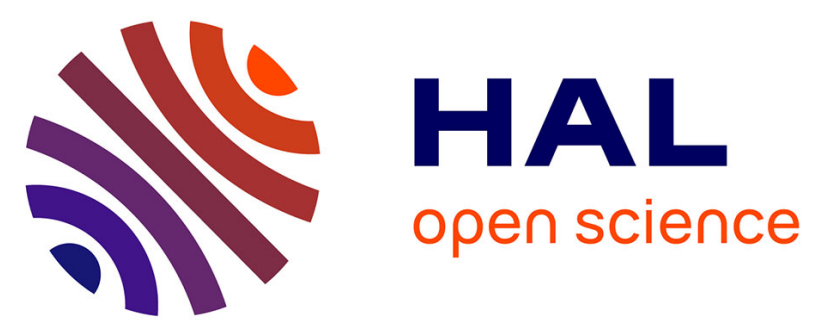

\title{
The non-peptidyl low molecular weight radical scavenger iac protects human pancreatic islets from lipotoxicity
} Valentina d'Aleo, Silvia del Guerra, Manuela Martano, Barbara Bonamassa, Donatella Canistro, Antonio Soleti, Luca Valgimigli, Moreno Paolini, Franco Filipponi, Ugo Boggi, et al.

\section{To cite this version:}

Valentina d'Aleo, Silvia del Guerra, Manuela Martano, Barbara Bonamassa, Donatella Canistro, et al.. The non-peptidyl low molecular weight radical scavenger iac protects human pancreatic islets from lipotoxicity. Molecular and Cellular Endocrinology, 2009, 309 (1-2), pp.63. 10.1016/j.mce.2009.05.010 . hal-00507139

\section{HAL Id: hal-00507139 \\ https://hal.science/hal-00507139}

Submitted on $30 \mathrm{Jul} 2010$

HAL is a multi-disciplinary open access archive for the deposit and dissemination of scientific research documents, whether they are published or not. The documents may come from teaching and research institutions in France or abroad, or from public or private research centers.
L'archive ouverte pluridisciplinaire HAL, est destinée au dépôt et à la diffusion de documents scientifiques de niveau recherche, publiés ou non, émanant des établissements d'enseignement et de recherche français ou étrangers, des laboratoires publics ou privés. 


\section{Accepted Manuscript}

Title: The non-peptidyl low molecular weight radical scavenger iac protects human pancreatic islets from lipotoxicity

Authors: Valentina D'Aleo, Silvia Del Guerra, Manuela Martano, Barbara Bonamassa, Donatella Canistro, Antonio

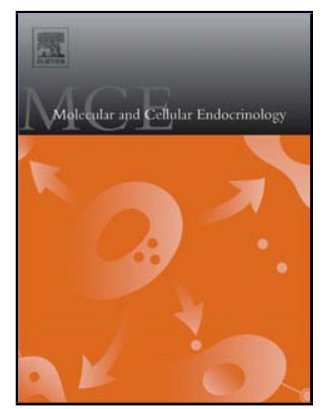

Soleti, Luca Valgimigli, Moreno Paolini, Franco Filipponi, Ugo Boggi, Stefano Del Prato, Roberto Lupi

PII: $\quad$ S0303-7207(09)00276-7

DOI: $\quad$ doi:10.1016/j.mce.2009.05.010

Reference: MCE 7223

To appear in: $\quad$ Molecular and Cellular Endocrinology

Received date: 22-1-2009

Revised date: $\quad$ 15-5-2009

Accepted date: $\quad$ 19-5-2009

Please cite this article as: D’Aleo, V., Del Guerra, S., Martano, M., Bonamassa, B., Canistro, D., Soleti, A., Valgimigli, L., Paolini, M., Filipponi, F., Boggi, U., Del Prato, S., Lupi, R., The non-peptidyl low molecular weight radical scavenger iac protects human pancreatic islets from lipotoxicity, Molecular and Cellular Endocrinology (2008), doi:10.1016/j.mce.2009.05.010

This is a PDF file of an unedited manuscript that has been accepted for publication. As a service to our customers we are providing this early version of the manuscript. The manuscript will undergo copyediting, typesetting, and review of the resulting proof before it is published in its final form. Please note that during the production process errors may be discovered which could affect the content, and all legal disclaimers that apply to the journal pertain. 
THE NON-PEPTIDYL LOW MOLECULAR WEIGHT RADICAL SCAVENGER IAC PROTECTS HUMAN PANCREATIC ISLETS FROM LIPOTOXICITY

Valentina D’Aleo ${ }^{1}$, Silvia Del Guerra ${ }^{1}$, Manuela Martano ${ }^{3}$, Barbara Bonamassa ${ }^{2}$, Donatella Canistro ${ }^{2}$, Antonio Soleti ${ }^{3}$, Luca Valgimigli ${ }^{5}$, Moreno Paolini ${ }^{2}$, Franco Filipponi ${ }^{4}$, Ugo Boggi ${ }^{4}$, Stefano Del Prato ${ }^{1}$, Roberto Lupi ${ }^{1}$.

1. Department of Endocrinology and Metabolism, Metabolic Unit, University of Pisa, Italy

2. Department of Pharmacology, Molecular Toxicology Unit, Alma Mater Studiorum, University of Bologna, Italy;

3. Medestea Research, Medestea, Torino, Italy;

4. Department of Oncology and Transplant Surgery, University of Pisa, Pisa, Italy

5. Department of Organic Chemistry “A. Mangini”, University of Bologna, Italy;

Key words: human pancreatic islet, oxidative stress, antioxidants, FFA, lipotoxicity.

Correspondence to:

Dr. Roberto Lupi, BHS

Department of Endocrinology and Metabolism - Metabolic Unit

Cisanello Hospital, via Paradisa 2

56100 Pisa - Italy

e-mail: lupir@immr.med.unipi.it

tel: +39050995134

fax: +39050541521 


\begin{abstract}
Background. Chronic exposure to high free fatty acids (FFA) can lead to irreversible damage of beta-cell accounting for impaired insulin secretion. Multiple mechanisms concur in generating the damage, but activation of oxidative stress may contribute to the final toxic effect. To better understand the phenomenon of lipotoxicity in human beta-cells, we evaluated the effects of 24-h preculture with $1.0 \mathrm{mmol} / \mathrm{I} \mathrm{FFA}$ on the function, survival and mRNA expression of several enzymes involved in the generation and scavenging of reactive oxygen species (ROS). Material and Methods. Human islets, prepared by collagenase digestion and density gradient purification from 9 pancreases of multiorgan donors were incubated for 24-hrs in the presence $1.0 \mathrm{mmol} / \mathrm{l}$ long-chain mixture (oleate:palmitate, 2:1) FFA, with or without $100 \mu \mathrm{mol} / \mathrm{I} \mathrm{IAC}$, a non-peptidyl low molecular weight radical scavenger. At the end of incubation period, insulin secretion was measured by static incubation, and mRNA expression of insulin, $\mathrm{Cu} / \mathrm{Zn}-\mathrm{SOD}, \mathrm{Mn}-\mathrm{SOD}$, Catalase, Glutathione peroxidase (GSH-px) and HO-1 by quantitative Real-Time RT-PCR. Nitrotyrosine levels were determined by an ELISA technique. Results. As compared to control incubation (Ctrl, no FFA), exposure to FFA was associated with impaired insulin release and reduced insulin mRNA expression. The presence of IAC in the incubation medium increased insulin release significantly and prevented changes in mRNA expression. Exposure to FFA was associated with oxidative stress as indicated by a significant accumulation of nitrotyrosine and IAC restrained such an increase. mRNA expression of $\mathrm{Cu} / \mathrm{Zn}-\mathrm{SOD}$, Mn-SOD, Catalase, GSH-Px, and HO-1 were all modified after FFA exposure. These changes were partially prevented in the presence of IAC. Conclusions. In human islets 24-hr exposure to high FFA causes oxidative stress associated with changes of several enzymes involved in ROS scavenging. These effects were prevented by the use of an antioxidant molecule.
\end{abstract}




\section{Introduction}

Under physiological conditions, free fatty acids (FFAs) sustain basal insulin secretion in the fasted state and potentiate hormone release in response to glucose (Randle, 1998). In contrast, prolonged exposure to increased FFA concentrations, as to occurs in diabetes and obesity, has detrimental effects on pancreatic beta-cells (Lupi et al., 2002), a phenomenon termed lipotoxicity. Together with other investigators, we have previously reported that prolonged exposure of pancreatic human islets to FFAs causes a dose-dependent inhibition of glucose-stimulated insulin release (Lupi et al., 2002). The toxic effect is exerted through activation of multiple mechanisms including accumulation of malonyl CoA and long-chain fatty acyl CoA (Maestre et al., 2003), increased fatty acid oxidation and esterification (Segall et al., 1999), accumulation of ceramide (Maestre et al., 2003) and fatty-acid induced apoptosis (Lupi et al., 2002).

Both hyperglycemia and FFAs can enhance formation of reactive oxygen species (ROS), causing cell protein and DNA damage. ROS generation by FFAs has been demonstrated in rodent pancreatic islets (Carlsson et al, 1999) and beta-cell lines (Wang et al., 2004; Oprescu et al., 2007). Moreover, animal studies have shown that oxidative stress can decrease beta-cell secretory function both in vitro and in vivo (Tang et al., 2007). The Beta-cell appears more vulnerable to oxidative stress due to very low activities of antioxidant enzymes, as indicated by low gene expression of superoxide dismutase, catalase, and glutathione peroxidase (Lenzen et al., 1996).

We have recently shown the efficacy of the new broad target cell penetrant antioxidant bis(1hydroxy-2,2,6,6-tetramethyl-4-piperidinyl)decandioate di-hydrochloride (IAC) molecule on pancreatic human islets (Lupi et al., 2007). Twenty-four hours exposure of type 2 diabetic islets to IAC reduces oxidative stress and improves glucose-stimulated insulin secretion (Lupi et al., 2007). Because presently little information is available as for the direct action of FFA on oxidative stress on human pancreatic islets, in the present report we describe the effects of $24 \mathrm{~h}$ exposure to FFA on islets prepared from non diabetes subjects, and the protective role of the antioxidant molecule IAC. 


\section{Materials and Methods}

\section{Islet preparation}

For this study eight pancreases from non-diabetic multiorgan donors (age, 66 \pm 13 years; gender, 5 males $/ 4$ females; body mass index, $25.7 \pm 4.2 \mathrm{~kg} / \mathrm{m}^{2}$ ) were used upon approval of the local Ethic Committee. Islets were prepared by collagenase digestion and density gradient purification, as previously reported (Lupi et al., 2002; Lenzen et al., 1996; Lupi et al., 2007). Three days after isolation, aliquots of approximately 500 hand-picked islets were free-floating cultured at $37^{\circ} \mathrm{C}$ and $5 \%$ of $\mathrm{CO}_{2}$ for $24 \mathrm{~h}$ with or without $1.0 \mathrm{mmol} / \mathrm{l}$ long-chain fatty-acid mixture (oleate:palmitate, 2:1, 6\% human albumin). Incubations were then repeated with or without 10 or $100 \mu \mathrm{mol} / \mathrm{l}$ bis(1-hydroxy-2,2,6,6tetramethyl-4-piperidinyl) decanedioate (IAC) (kindly provided by Medestea, Torino, Italy), added each 48h. The final $\mathrm{pH}$ of all media was buffered at $\mathrm{pH} 7.4$.

\section{Determination of oxidative stress}

Oxidative stress in isolated islets was determined by measuring nitrotyrosine concentrations by an ELISA method as previously demonstrated (Lenzen et al., 1996). In 4 experiments we took advantage of IAC to measure oxidative stress also from nitroxide analysis by electron paramagnetic resonance (EPR) (Valgimigli et al., 2000; Valgimigli et al., 2001). This approach uses IAC as a probe since, after having accomplished its antioxidant role, IAC is transformed in the corresponding nitroxide that can be quantified by EPR. Therefore, the method allows simultaneous assessment of ROS production (by EPR) and use of IAC as an antioxidant agent (Lenzen et al., 1996; Valgimigli et al., 2000; Valgimigli et al., 2001).

\section{Gene expression studies}

Messenger RNA expression of $\mathrm{Cu} / \mathrm{Zn}-\mathrm{SOD}, \mathrm{Mn}-\mathrm{SOD}$, catalase, glutathione peroxidase (GSH-px), HO-1, BCl2, BAX, insulin, GLUT-2 and glucokinase (GK) were measured by quantitative Real-Time Reverse Transcription reaction (Real-Time RT-PCR) (Lenzen et al., 1996; Lupi et al., 2007). Total RNA was extracted from the islets by using the RNeasy Protect Mini Kit (QIAGEN) and quantified by absorbance at $A_{260} / A_{280}$ (ratio>1.65) $\mathrm{nm}$ in a Perkin-Elmer spectrophotometer. Its integrity was assessed after electrophoresis in $1.0 \%$ agarose gels by ethidium bromide staining. The primers and 
probes sequences were obtained from PE Applied Biosystems (Pre-Developed TaqMan Assay Reagents Control Kits). The quantity of each cDNA sample was normalized to the housekeeping gene for cyclophilin $A(n=8)$.

\section{Assessment of Islets cell viability}

A simultaneous double-staining procedure using fluoresceine diacetate (FDA) and propidium iodide (PI) for determination of cell viability in islet cell suspension was performed adapting the method of Jones $\mathrm{KH}$ et al. (Jones and Senft, 1985) to human pancreatic islets. Viable cells express bright green fluorescence, while non viable cells turn bright red. FDA (Inalco S.p.A., Milano - Italy) was prepared dissolving $1 \mathrm{mg}$ powder in $1 \mathrm{ml}$ of acetone and PI (Inalco S.p.A., Milano - Italy) was prepared dissolving $2 \mathrm{mg}$ of powder in $1 \mathrm{ml}$ of PBS. Briefly, aliquots of about 30 islets were washed twelve times in KREBS ringer bicarbonate and incubated for $30 \mathrm{~min}$ free-floating at $37^{\circ} \mathrm{C}$ and $5 \%$ of $\mathrm{CO}_{2}$ in $1 \mathrm{ml}$ of $\mathrm{M} 199$ culture medium containing $4 \mu \mathrm{l}$ of FDA and $2 \mu \mathrm{l}$ of PI. At the end of the incubation period, islets were gently centrifuged, washed two times in PBS and re- suspended in $200 \mu \mathrm{l}$ of MilliQ water. FDA and PI were immediately analyzed on fluorescence microplate reader with excitation respectively at 492 and 536-nm and emission respectively at 518 and 617-nm $(n=8)$.

\section{Insulin secretion study}

Insulin secretion studies were performed by the batch incubation method, as previously detailed (Lupi et al., 2002; Lenzen et al., 1996; Lupi et al., 2007). Following a 45 min pre-incubation period at 3.3 $\mathrm{mmol} / \mathrm{l}$ glucose, islets were kept at $37{ }^{\circ} \mathrm{C}$ for $45 \mathrm{~min}$ in Krebs-Ringer bicarbonate solution (KRB), $0.5 \%$ albumin, pH 7.4, containing $3.3 \mathrm{mmol} / \mathrm{l}$ glucose. At the end of this period, medium was completely removed and replaced with KRB containing either 3.3 or $16.7 \mathrm{mmol} / \mathrm{l}$ glucose. After additional $45 \mathrm{~min}$ incubation, media were removed. Samples $(500 \mu \mathrm{l})$ from the different media were stored at $-20{ }^{\circ} \mathrm{C}$ for determination of insulin concentrations by immunoradiometric assay technique (IRMA) $(n=8)$. 


\section{Statistical analysis}

Results are expressed as means \pm SD. Comparison between two groups were performed by the two-tailed Student's t-test, whereas comparisons among multiple groups were done by ANOVA, followed by the Bonferroni correction to test differences between specific conditions.

\section{Results}

\section{Oxidative stress evaluation}

Incubation of human pancreatic islets in the presence of $1 \mathrm{mmol} / \mathrm{I} F \mathrm{FA}$ was associated with increased of oxidative stress, as indicated by the EPR technique $(p<0.001)$ (Figure 1), and by accumulation of intracellular nitrotyrosine $(p<0.05)$ (Figure 2$)$. Oxidative stress was paralleled by significantly reduction of $\mathrm{Cu} / \mathrm{Zn}-\mathrm{SOD}$ mRNA expression and by significant increase of catalase, GSH-px and HO-1 mRNA expression (Table 1).

As shown in Figure 2, $10 \mu \mathrm{mol} / \mathrm{I} \mathrm{IAC}$ was sufficient to reduce nitrotyrosine concentration by $32 \%$ $(p<0.05)$, while $100 \mu \mathrm{mol} / \mathrm{I}$ IAC caused a $44 \%$ of reduction of the oxidative stress marker $(p<0.05)$. These changes were mirrored by consensual response in the mRNA expression of oxidant and antioxidant enzymes, as demonstrated in Table 1.

Islet function study

Oxidative stress induced by FFA was accompanied by marked changes in islet function, as indicated by impaired glucose-stimulated insulin release (Figure 3), and in a significant reduction of insulin, GLUT-2, and GK mRNA expression (Table 2). As shown in Figure 3 and Table 2, the adding of 10 and $100 \mu \mathrm{mol} / \mathrm{I}$ IAC to culture media significantly increased the glucose-stimulated insulin secretion and gene expression.

Islets cell viability

The presence of FFA in culture medium resulted in significant reduction of cell viability (FFA: $21.99 \pm 17.18 \%$. Ctrl: $77.42 \pm 15.53 \%)$, with 3.4 fold increase in the ratio between pro-apoptotic BAX/anti-apoptotic $\mathrm{BCl} 2$ gene expression (Table 3). Incubation of human islets with IAC preserved cell viability (IAC $10 \mu \mathrm{ml} / \mathrm{I}, 69.2 \pm 10.45 \%$; IAC $100 \mu \mathrm{mol} / \mathrm{l}, 79.1 \pm 1.62 \%$. both $\mathrm{p}<0.05$ ) and significantly reduced the $\mathrm{BAX} / \mathrm{BCl} 2$ ratio (IAC $10 \mu \mathrm{ml} / \mathrm{l}, 0.91 \pm 0.08$; IAC $100 \mu \mathrm{mol} / \mathrm{l}, 0.57 \pm 0.04$. both $\mathrm{p}<0.05$ ) (Table $3)$. 


\section{Conclusions}

Lipotoxicity is a well known phenomenon accounting for impairment of beta-cell function (Ayvaz et al., 2002). It is believed to contribute to progressive decline of insulin secretion occurring in type 2 diabetic patients who commonly present chronic elevation of free-fatty acids (Poitout and Robertson, 2002). A large literature has illustrated the potential mechanisms responsible for toxic effect of FFA on the beta-cell (Poitout and Robertson, 2002; McGarry and Dobbins, 1999). Among these, oxidative stress may play a role. Our study, performed with human pancreatic islets support this view, because of direct evidence that exposure of islets to $1.0 \mathrm{mmol} / \mathrm{I}$ FFA is associated with 1 . accumulation of nitrotyrosine, 2 . consensual changes in the mRNA expression of oxidative stressrelated enzymes, 3. impaired glucose-stimulated insulin release, and 4. lower cell viability along with $\mathrm{BAX} / \mathrm{BCl} 2$ ratio. Finally, use of the novel antioxidant bis(1-hydroxy-2,2,6,6-tetramethyl-4-piperidinyl) decanedioate (IAC) resulted in an almost complete protection from lipotoxicity.

These results support previous observations indicating oxidative stress as an effector of lipotoxicity. In agreement with some previous data of ours (Lupi et al., 2002), prolonged exposure to FFA caused cytostatic and pro-apoptotic effect. In, that experience we reported that the increased amount of dead cell following FFA exposure was accounted for by increased apoptosis. Therefore, even if not directly tested here, we are confident that activation of apoptotic process is the main reason for poor cell survival. In support of this interpretation is the marked changes in the ratio between mRNA expression of pro-apoptotic protein BAX and the anti-apoptotic one, BCl2. FFA-induced apoptosis has been shown to be mediated by ceramide accumulation in beta-cell (Summers, 2006) but, rather than being an alternative mechanism, oxidative stress can be accelerated by ceramide as suggested by Shimabukuro et al. (Shimabukuro et al., 1998).

Previous work (Piro et al., 2002) showed that nicotinamide could prevent FFA-induced apoptosis but no direct assessment of oxidative stress was performed in that study. Interestingly, we have previously reported an anti lipotoxic effect of PPAR-gamma agonists (Lupi et al., 2004). Although not directly observed in that study, glitazones posses an antioxidant properties (May and Qu, 2000). At presence we provide direct assessment for that, by determination of nitrotyrosine and EPR measurement, showing that FFA can indeed result in ROS generation. Similar results have been obtained in rat islets incubated in the presence of palmitate (Lameloise et al., 2001). However, in these animals, 
the effect of FFA-induced oxidative stress has been questioned since no effect on glucose-stimulated insulin secretion was observed upon $72 \mathrm{~h}$ exposure of rat islets to FFA, ceramides, or ROS formation (Moore et al., 2004). Whether such a resistance may be explained by slight uncoupling electron transport observed under similar condition (Joseph et al., 2004) remains unclear.

In spite of apparent relationship between FFA and ROS generation, the mechanism by which oxidative stress is generated remains partially understood. In insulin secreting cells, FFA can inhibit respiratory chain (Koshkin et al., 2003), while ceramide has been shown to affect its efficiency (Schönfeld and Wojtczak, 2007). Moreover, FFA can activate NADPH-oxidase as indicated by increased expression of p47 $7^{\text {phox }}$ (Morgan et al., 2007). Whatever the mechanism is, the effect of IAC was evident and marked. When, added to the culture medium together with FFA only minor activation of oxidative stress occurred as indicated by non significant changes of nitrotyrosine concentration and prevention of both cytostatic and pro-apoptotic effects. Gene expression and activity of the main antioxidant enzymes are much lower in pancreatic islets than in other tissues (Tiedge et al., 1998; Lenzen et al., 1996). We, therefore, have directly assessed responses of mRNA expression of Cu/Zn-SOD, catalase, Mn-SOD, GSH-px and HO-1. In response to FFA exposure, SODs mRNA expression decreased while catalase, GSH-px and HO-1 increased. All these changes were, at least partially, reverted by IAC, again emphasizing a direct relationship between FFA availability, formation of oxidative stress, and cytostatic and pro-apoptotic effects.

Our results may also have some practical implications. Type 2 diabetic patients, particularly those with abdominal obesity, in addition to hyperglicemia, are characterized by increased FFA levels (Golay et al., 1990). Therefore, the use of antidiabetic agents that may reduce plasma FFA levels while exerting an antioxidant effect may have some potential in preserving beta-cell function.

In conclusion, reducing oxidative stress in islet cell exposed to FFA seems to be an effective method to improve beta-cell function and survival, suggesting that the antioxidant treatment may protect human islet beta-cell against injuries of lipotoxicity. 


\section{Legend to Figures}

Figure 1. Increased oxidative stress in FFA islets compared to Ctrl islets, evaluated by EPR radicalprobe technique $\left({ }^{*} p<0.001\right)$

Figure 2. Nitrotyrosine level in Ctrl compared to FFA islets, with or without addition of IAC. The marker of oxidative stress level is significantly higher in FFA respect to Ctrl islets. IAC was able to significantly reduce the nitrotyrosine concentration respect to FFA alone $\left(^{*}=p<0.05\right.$ vs Ctrl by Bonferroni t-test correction; $\#=p<0.05$ vs FFA alone by Bonferroni t-test correction).

Figure 3. Stimulation Index (ratio between $16.7 \mathrm{mmol} / \mathrm{l}$ and $3.3 \mathrm{mmol} / \mathrm{l}$ glucose-stimulated insulin release) in Ctrl islets, FFA islets and FFA islets exposed or not to 10 and $100 \mu \mathrm{mol} / \mathrm{I}$ IAC. 
Table 1. $\mathrm{Cu} / \mathrm{Zn}-\mathrm{SOD}$, Catalase, Mn-SOD, GSH-px HO-1 mRNA expression in Ctrl islets and FFA islets before and after exposure to 10 or $100 \mu \mathrm{mol} / \mathrm{I} \mathrm{IAC}$.

\begin{tabular}{|c|c|c|c|c|c|}
\hline & Cu/Zn-SOD & Catalase & Mn-SOD & GSH-px & HO-1 \\
\hline Ctrl & 1 & 1 & 1 & 1 & 1 \\
\hline FFA 1.0 mmol/I & $0.510 \pm 0.134^{*}$ & $2.703 \pm 0.971^{*}$ & $0.361 \pm 0.107$ & $1.841 \pm 0.416^{*}$ & $2.242 \pm 0.701^{*}$ \\
\hline $\begin{array}{c}\text { FFA+IAC 10 } \\
\mu \mathrm{mol} / \mathrm{I}\end{array}$ & $0.619 \pm 0.124^{*}$ & $1.590 \pm 0.223$ & $1.875 \pm 0.592^{*}$ & $1.521 \pm 0.286^{*}$ & $1.309 \pm 0.073$ \\
\hline $\begin{array}{c}\text { FFA+IAC 100 } \\
\mu \mathrm{mol} / \mathrm{I}\end{array}$ & $0.623 \pm 0.222^{*}$ & $1.264 \pm 0.185$ & $1.828 \pm 0.941^{*}$ & $1.339 \pm 0.068$ & $1.159 \pm 0.352$ \\
\hline
\end{tabular}

Measurements were made by real-time RT-PCR, and normalized for values in ctrl.

$*=p<0.05$ vs Ctrl by Bonferroni t-test correction

Table 3. Pro-apoptotic $B A X$ and anti-apoptotic $B C l 2$ mRNA expression in Ctrl islets and FFA islets before and after exposure to 10 or $100 \mu \mathrm{mol} / \mathrm{I} \mathrm{IAC}$.

\begin{tabular}{|c|c|c|c|}
\hline & BAX & BCl2 & BAX/BCl2 \\
\hline Ctrl & 1 & 1 & 1 \\
\hline FFA 1.0 mmol/I & $1.55 \pm 0.07^{*}$ & $0.45 \pm 0.06^{*}$ & $3.44 \pm 0.80^{*}$ \\
\hline $\begin{array}{c}\text { FFA+IAC 10 } \\
\mu \mathrm{mol} / \mathrm{I}\end{array}$ & $1.0 \pm 0.14^{\#}$ & $1.10 \pm 0.28^{\#}$ & $0.91 \pm 0.08^{\#}$ \\
\hline $\begin{array}{c}\text { FFA+IAC 100 } \\
\mu \mathrm{mol} / \mathrm{I}\end{array}$ & $0.79 \pm 0.01^{* \#}$ & $1.39 \pm 0.04^{* \#}$ & $0.57 \pm 0.04^{\#}$ \\
\hline
\end{tabular}

Measurements were made by real-time RT-PCR, and normalized for values in ctrl.

$*=p<0.05$ vs Ctrl by Bonferroni t-test correction

$\#=p<0.05$ vs FFA alone by Bonferroni t-test correction 
Table 2. Insulin, GLUT-2 and Glucokinase (GK) mRNA expression in Ctrl islets and FFA islets before and after exposure to 10 or $100 \mu \mathrm{mol} / \mathrm{I}$ IAC.

\begin{tabular}{|c|c|c|c|}
\hline & Insulin & GLUT2 & GK \\
\hline Ctrl & 1 & 1 & 1 \\
\hline FFA 1.0 mmol/I & $0.47 \pm 0.05^{*}$ & $0.40 \pm 0.14^{*}$ & $0.56 \pm 0.06^{*}$ \\
\hline $\begin{array}{c}\text { FFA+IAC 10 } \\
\mu \mathrm{mol} / \mathrm{I}\end{array}$ & $1.0 \pm 0.14^{\#}$ & $0.65 \pm 0.06^{* \#}$ & $1.40 \pm 0.28^{* \#}$ \\
\hline $\begin{array}{c}\text { FFA+IAC 100 } \\
\mu \mathrm{mol} / \mathrm{I}\end{array}$ & $1.15 \pm 0.07^{* \#}$ & $0.95 \pm 0.07^{\#}$ & $1.35 \pm 0.07^{* \#}$ \\
\hline
\end{tabular}

Measurements were made by real-time RT-PCR, and normalized for values in ctrl.

$*=p<0.05$ vs Ctrl by Bonferroni t-test correction

$\#=p<0.05$ vs FFA alone by Bonferroni t-test correction 


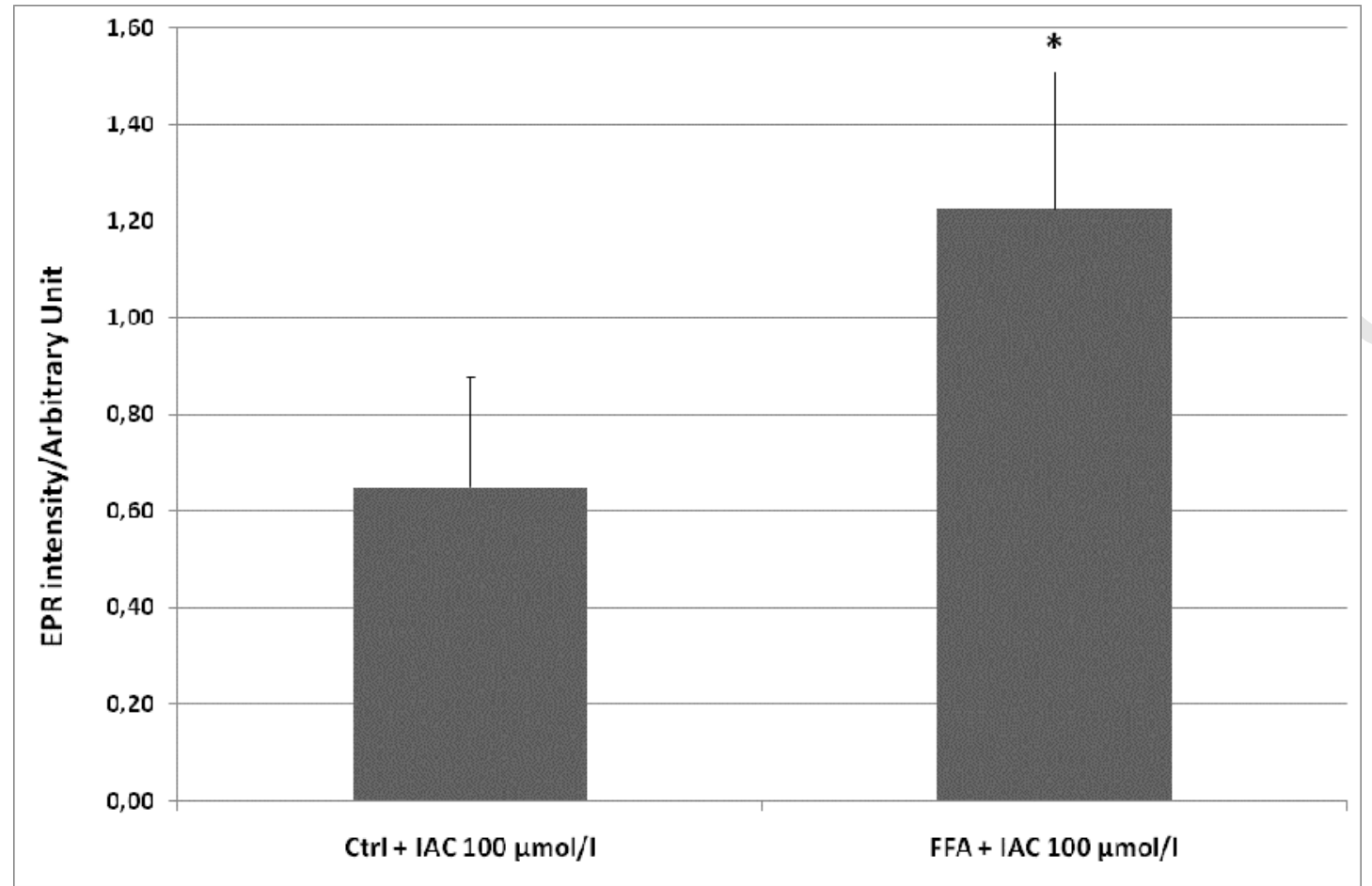

Figure 1

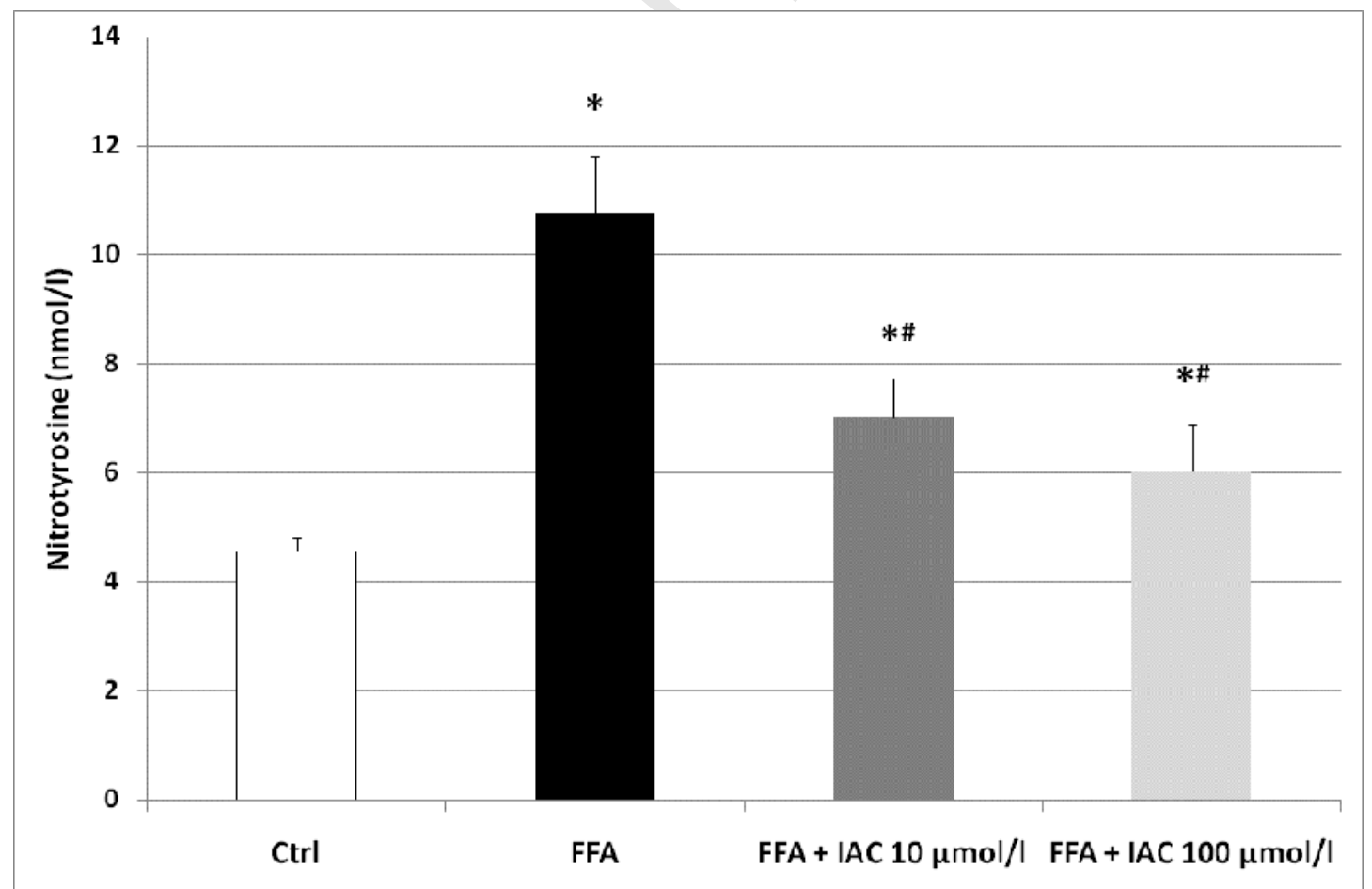

Figure 2 


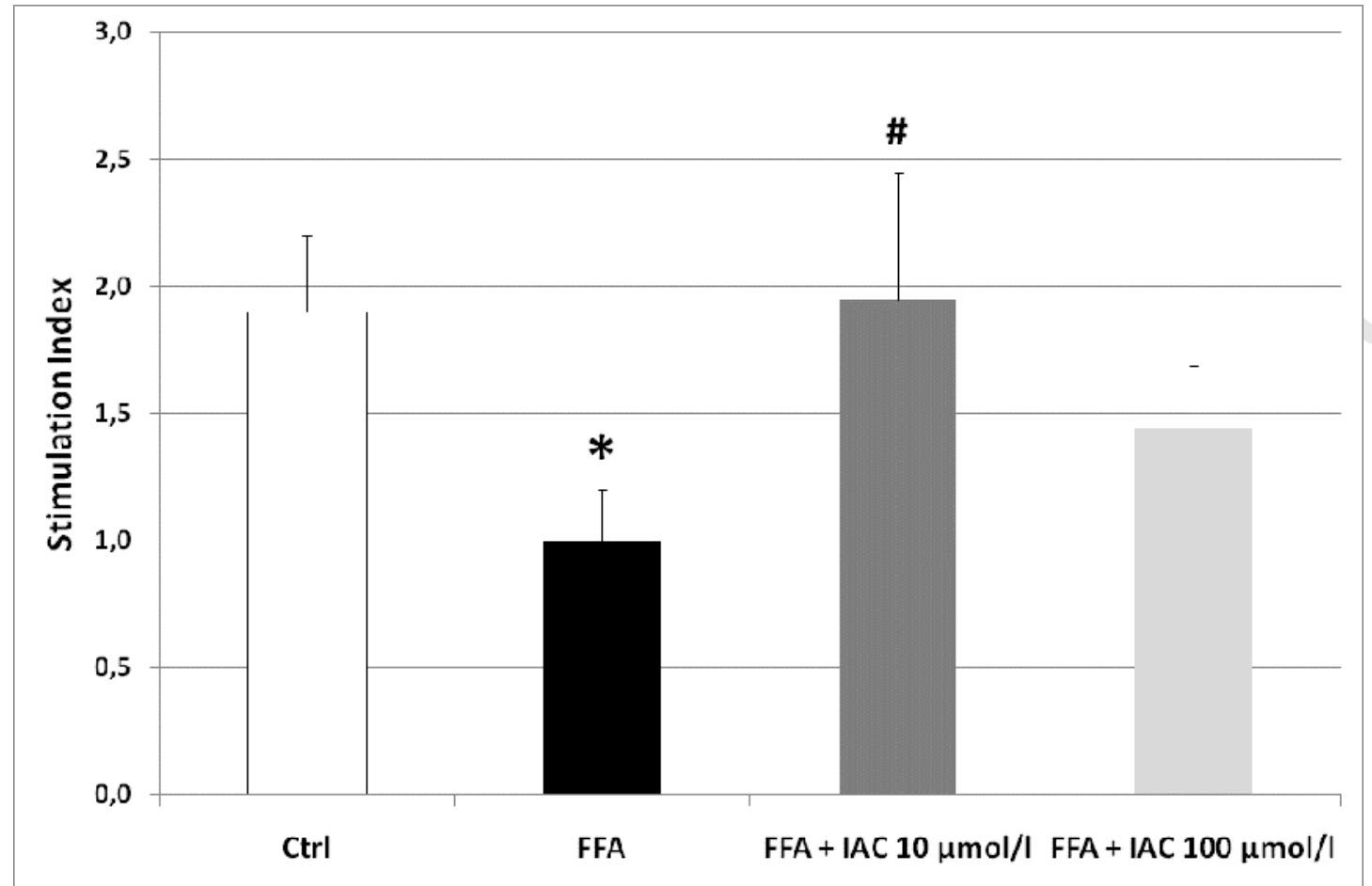

Figure 3 


\section{References}

Ayvaz, G., Balos Toruner, F., Karakoc, A., Yetkin, I., Cakir, N., Arslan, M., 2002. Acute and chronic effects of different concentrations of free fatty acids on the insulin secreting function of islets. Diabetes Metab. 28, S7-S12.

Carlsson, C., Borg, L.A., Welsh, N., 1999. Sodium palmitate induces partial mitochondrial uncoupling and reactive oxygen species in rat pancreatic islets in vitro. Endocrinology 140, 3422-3428.

Golay, A., Chen, N., Chen, Y.D., Hollenbeck, C., Reaven, G.M., 1990. Effect of central obesity on regulation of carbohydrate metabolism in obese patients with varying degrees of glucose tolerance. J. Clin. Endocrinol. Metab. 71(5), 1299-1304.

Jones, K.H., Senft, J.A., 1985. An improved method to determine cell viability by simultaneous staining with fluorescein diacetate-propidium iodide. J. Histochem. Cytochem. 33(1), 77-79.

Joseph, J.W., Koshkin, V., Saleh, M.C., Sivitz, W.I., Zhang, C.Y., Lowell, B.B., Chan, C.B., Wheeler, M.B., 2004. Free fatty acid-induced beta-cell defects are dependent on uncoupling protein 2 expression. J. Biol. Chem. 279(49), 51049-51056.

Koshkin, V., Wang, X., Scherer, P.E., Chan, C.B., Wheeler, M.B., 2003. Mitochondrial functional state in clonal pancreatic beta-cells exposed to free fatty acids. J. Biol. Chem. 278(22), 19709-19715.

Lameloise, N., Muzzin, P., Prentki, M., Assimacopoulos-Jeannet, F., 2001. Uncoupling protein 2: a possible link between fatty acid excess and impaired glucose-induced insulin secretion? Diabetes. 50(4), 803-809.

Lenzen, S., Drinkgern, J., Tiedge, M., 1996. Low antioxidant enzyme gene expression in pancreatic islets compared with various other mouse tissues. Free Radic. Biol. Med. 20, 463-466.

Lupi, R., Del Guerra, S., Mancarella, R., Novelli, M., Valgimigli, L., Pedulli, G.F., Paolini, M., Soleti, A, Filipponi, F., Mosca, F., Boggi, U., Del Prato, S., Masiello, P., Marchetti, P., 2007. Insulin secretion defects of human type 2 diabetic islets are corrected in vitro by a new reactive oxygen species scavenger. Diabetes Metab. 33(5), 340-345.

Lupi, R., Del Guerra, S., Marselli, L., Bugliani, M, Boggi, U., Mosca, F., Marchetti, P., Del Prato, S., 2004. Rosiglitazone prevents the impairment of human islet function induced by fatty acids: evidence for a role of PPARgamma2 in the modulation of insulin secretion. Am. J. Physiol. Endocrinol. Metab 286(4), E560-E567. 
Lupi, R., Dotta, F., Marselli, L., Del Guerra, S., Masini, M., Santangelo, C., Patané, G., Boggi, U., Piro, S., Anello, M., Bergamini, E., Mosca, F., Di Mario, U., Del Prato, S., Marchetti, P., 2002. Prolonged exposure to free fatty acids has cytostatic and pro-apoptotic effects on human pancreatic islets: evidence that beta-cell death is caspase mediated, partially dependent on ceramide pathway, and $\mathrm{Bcl}-2$ regulated. Diabetes 51 (5), 1437-42.

Maestre, I., Jordan, J., Calvo, S., Reig, J.A., Cena, V., Soria, B., Prentki, M., Roche, E., 2003. Mitochondrial dysfunction is involved in apoptosis induced by serum withdrawal and fatty acids in the beta-cell line INS-1. Endocrinology 144, 335-345.

May, J.M., Qu, Z.C., 2000. Troglitazone protects human erythrocytes from oxidant damage. Antioxid. Redox. Signal. 2(2), 243-250.

McGarry, J.D., Dobbins, R.L., 1999. Fatty acids, lipotoxicity and insulin secretion. Diabetologia 42, 128138.

Moore, P.C., Ugas, M.A., Hagman, D.K., Parazzoli, S.D., Poitout, V., 2004. Evidence against the involvement of oxidative stress in fatty acid inhibition of insulin secretion. Diabetes. 53(10), 26102616

Morgan, D., Oliveira-Emilio, H.R., Keane, D., Hirata, A.E., Santos da Rocha, M., Bordin, S., Curi, R., Newsholme, P., Carpinelli, A.R., 2007. Glucose, palmitate and pro-inflammatory cytokines modulate production and activity of a phagocyte-like NADPH oxidase in rat pancreatic islets and a clonal beta cell line. Diabetologia. 50(2), 359-369

Oprescu, A.I., Bikopoulos, G., Naassan, A., Allister, E.M., Tang, C., Park, E., Uchino, H., Lewis, G.F., Fantus, I.G., Rozakis-Adcock, M., Wheeler, M.B., Giacca, A., 2007. Free fatty acid-induced reduction in glucose-stimulated insulin secretion: evidence for a role of oxidative stress in vitro and in vivo. Diabetes 56(12), 2927-37.

Piro, S., Anello, M., Di Pietro, C., Lizzio, M.N., Patanè, G., Rabuazzo, A.M., Vigneri, R., Purrello, M., Purrello, F., 2002. Chronic exposure to free fatty acids or high glucose induces apoptosis in rat pancreatic islets: possible role of oxidative stress. Metabolism. 51(10), 1340-1347.

Poitout, V., Robertson, R.P., 2002. Minireview: Secondary beta-cell failure in type 2 diabetes-a convergence of glucotoxicity and lipotoxicity. Endocrinology 143, 339-342. 
Randle, P.J., 1998. Regulatory interactions between lipids and carbohydrates: the glucose fatty acid cycle after 35 years. Diabetes Metab. Rev. 14(4), 263-83.

Schönfeld, P., Wojtczak, L., 2007. Fatty acids decrease mitochondrial generation of reactive oxygen species at the reverse electron transport but increase it at the forward transport. Biochim. Biophys. Acta. $1767(8), 1032-1040$.

Segall, L., Lameloise, N., Assimacopoulos-Jeannet, F., Roche, E., Corkey, P., Thumelin, S., Corkey, B.E., Prentki, M., 1999. Lipid rather than glucose metabolism is implicated in altered insulin secretion caused by oleate in INS-1 cells. Am. J. Physiol. 277(3 Pt 1), E521-E528.

Shimabukuro, M., Zhou, Y.T., Levi, M., Unger, R.H., 1998. Fatty acid-induced beta cell apoptosis: a link between obesity and diabetes. Proc. Natl. Acad. Sci. U S A. 95(5), 2498-2502.

Summers, S.A., 2006. Ceramides in insulin resistance and lipotoxicity. Prog. Lipid. Res. 45(1), 42-72.

Tang, C., Han, P., Oprescu, A.I., Lee, S.C., Gyulkhandanyan, A.V., Chan, G.N., Wheeler, M.B., Giacca, A., 2007. Evidence for a role of superoxide generation in glucose-induced beta-cell dysfunction in vivo. Diabetes 56(11), 2722-31.

Tiedge, M., Lortz, S., Munday, R., Lenzen, S., 1998. Complementary action of antioxidant enzymes in the protection of bioengineered insulin-producing RINm5F cells against the toxicity of reactive oxygen species. Diabetes. 47(10), 1578-1585.

Valgimigli, L., Pedulli, G.F., Paolini, M., 2001. Measurement of oxidative stress by EPR radical-probe technique. Free Radic. Biol. Med. 31(6), 708-716.

Valgimigli, L., Valgimigli, M., Gaiani, S., Pedulli, G.F., Bolondi, L., 2000. Measurement of oxidative stress in human liver tissue by EPR spin-probe technique. Free Radic. Res. 33, 167-178.

Wang, X., Li, H., De Leo, D., Guo, W., Koshkin, V., Fantus, I.G., Giacca, A., Chan, C.B, Der, S., Wheeler, M.B., 2004. Gene and protein kinase expression profiling of reactive oxygen species-associated lipotoxicity in the pancreatic ß-cell line MIN6. Diabetes 53, 129-140. 